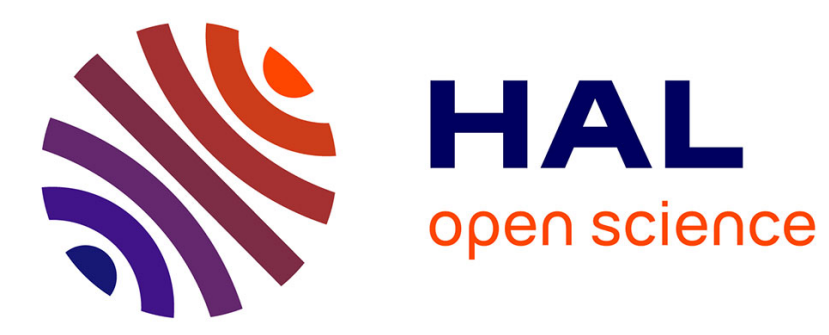

\title{
STRUCTURE AND POLYMORPHISM OF THE HYDROCARBON CHAINS OF LIPIDS : A STUDY OF LECITHIN-WATER PHASES
}

A. Tardieu, V. Luzzati, F. Reman

\section{- To cite this version:}

A. Tardieu, V. Luzzati, F. Reman. STRUCTURE AND POLYMORPHISM OF THE HYDROCARBON CHAINS OF LIPIDS : A STUDY OF LECITHIN-WATER PHASES. Journal de Physique Colloques, 1973, 34 (C8), pp.C8-2-C8-2. 10.1051/jphyscol:1973802 • jpa-00215355

HAL Id: jpa-00215355 https://hal.science/jpa-00215355

Submitted on 1 Jan 1973

HAL is a multi-disciplinary open access archive for the deposit and dissemination of scientific research documents, whether they are published or not. The documents may come from teaching and research institutions in France or abroad, or from public or private research centers.
L'archive ouverte pluridisciplinaire HAL, est destinée au dépôt et à la diffusion de documents scientifiques de niveau recherche, publiés ou non, émanant des établissements d'enseignement et de recherche français ou étrangers, des laboratoires publics ou privés. 


\title{
STRUCTURE AND POLYMORPHISM OF THE HYDROCARBON CHAINS OF LIPIDS : A STUDY OF LECITHIN-WATER PHASES $\left(^{*}\right)$
}

\author{
A. TARDIEU, V. LUZZATI \\ Centre de Génétique Moléculaire, CNRS \\ 91190 Gif-sur-Yvette, France \\ and \\ F. C. REMAN - \\ Biochemisch Laboratorium der Rijks Universiteit \\ Vondelaan 26, Utrecht, Holland
}

\begin{abstract}
This work describes the structure of a variety of lecithin-water phases observed below the «melting » temperature of the hydrocarbon chains, with special emphasis on the conformation of the chains. The lecithins studied in this work are the homologous series dioctanoyl to distearoyl, 2-decanoyl-1-stearoyl, and a preparation from hen eggs. The hydrocarbon chains are found to adopt a variety of conformations in additions to type $\alpha$, the liquid-like organization observed above the melting temperature. Type $\beta$ : the chains are stiff and parallel, oriented at right angles to the plane of the lamellae and packed with rotational disorder in a two-dimensional hexagonal lattice $(a \sim 4.85 \AA)$. Type $\beta^{\prime}:$ similar to $\beta$, but with the chains tilted with respect to the normal to the lamellae. Type $\delta:$ the chains are probably coiled into helices, whose axes are perpendicular to the plane of the polar groups and are packed with rotational disorder in a twodimensional square lattice $(a \sim 4.80 \AA)$. $\alpha$ is the predominant conformation, common to most lipids in the presence of water and at sufficiently high temperature, and the one more relevant to membranes; $\beta$ is observed at lower temperatures in lipids whose chains are heterogeneous and in the presence of very small amounts of water ; $\beta^{\prime}$ is found in synthetic lecithins with identical chains, in the presence of variable amounts of water $\delta$ is observed in dry lecithins. A highly ordered crystalline phase, yet displaying rotational disorder of the chains, is observed in almost dry lecithins. Most of the phases are lamellar, and contain one lipid bilayer per repeat unit. Two phases display two-dimensional lattices : $\mathbf{P} \delta$, formed by ribbon-like elements with the chains in the $\delta$ conformation; $\mathbf{P} \beta^{\prime}$, formed by lamellae of type $\beta^{\prime}$ distorted by periodic ripples. The results emphasize the clear-cut difference between the liquid-like and the other types of partly ordered conformations, as well as the correlations which exist between the chemical composition and the structure of the lipids below the melting temperature of the chains.
\end{abstract}

(*) Reprinted from J. Mol. Biol. 75 (1973) $711-733$. 